Brit.J. vener. Dis. (1963), 39, 206.

\title{
OBITUARY
}

\section{LINCOLN GWESYN GOBERT JONES, 1918-1963}

Dr. L. G. G. Jones, consultant venereologist to the Coventry and Warwickshire Hospital Group, died suddenly on May 28, 1963, while on holiday in Spain. He was born on August 5, 1918, educated at Aberystwyth and later in H.M. Cadet Ship Conway, and studied medicine at Liverpool University. After qualification in 1943 and resident posts at the Royal Infirmary and Walton Hospital, Liverpool, he joined the R.N.V.R. and served with the Coastal Forces in the English Channel and later in Far Eastern waters and Australia. For a time he was in charge of the genito-urinary ward in H.M.S. Empire Clyde and this experience encouraged him to make his career in venereology. He worked in London from 1947 to 1956, chiefly at St. Mary's Hospital, Paddington, obtained the M.R.C.P. Ed. in 1955 and, between 1951 and 1953, served in Syria and Iraq as chief medical adviser to the W.H.O. and U.N.I.C.E.F. bejel project. In 1956 he went to the Caribbean Medical Centre in Trinidad and these overseas appointments gave him a unique knowledge of the treponematoses. After three years as Assistant Venereologist in Manchester he became consultant in 1960 to the Coventry and Warwickshire Hospital Group where his experience and abilities were quickly recognized by his colleagues in all specialties.
In both the Manchester and Birmingham areas the high standard of his professional work, his genial personality, and his sense of humour quickly gained for him the respect and affection of all those who worked with him and he was immensely popular with his patients. Coronary thrombosis struck him down in 1961 but he soon returned to work and his sudden death has left us all with a great sense of loss. He will be remembered by many who feel richer for having known him. $\quad$ W. F. and S.M.L.

A contemporary at St. Mary's Hospital adds the following tribute:

Gobert Jones was an individualist; undoubtedly a Welshman and proud of it, he enjoyed speaking his native language. A good doctor, he was interested not only in his subject but also in his patients; some still ask for him at St. Mary's six years after his departure. He was an excellent colleague and was indispensable at a good party. However, when he decided that a "Membership" was necessary, he gave up all social activities for some months while he "read the books" and passed the Edinburgh M.R.C.P. examination at his first attempt.

"Gobi" was a good friend who is sadly missed by many of us. 